\title{
Atrio-ventricularis reentry tachycardia az AV-csomó kihagyásával, avagy kettős járulékos köteg fiatal, egészséges betegnél
}

\author{
Piros Katalin, Nagy Klaudia Vivien, Szegedi Nándor, Osztheimer István, \\ Salló Zoltán, Perge Péter, Herczeg Szilvia, Merkely Béla, Gellér László
}

Semmelweis Egyetem, Városmajori Szív- és Érgyógyászati Klinika, Budapest

Levelezési cím: piroskati90@gmail.com

Bevezetés: A WPW-szindróma prevalenciája az átlagpopulációban 0,15-0,25\%, WPW-szindrómával élő első fokú rokonok esetében magasabb, 0,55\%. Ebstein-anomália jelenléte esetén gyakoriak (52\%) a többszörös kötegek, míg a fejlődési rendellenesség nélküli, strukturálisan ép szívű betegekben ez jóval ritkább (13\%). Tünetes WPW-szindrómával élő betegek esetében a katéterabláció az elsőként választandó terápiás módszer.

Esetbemutatás: 41 éves férfi beteg jelentkezett Klinikánkon ismert belgyógyászati betegség nélkül. Ez év márciusában adenosinra szűnő, reguláris, keskeny QRS-tachycardia miatt kezelték, majd júliusban széles QRS-tachycardia miatt kardioverzió történt. Nyugalmi szívultrahangon jó bal kamrai ejekciós frakció (LVEF: 60\%) igazolódott, falmozgászavar, vitium nélkül. Nyugalmi EKG-n delta-hullám volt látható, azonban bal és jobb oldali kötegre is utaló eltérésekkel. Klinikánkon alkalmazott standard protokoll szerint végzett elektrofiziológiai vizsgálat során bal és jobb laterális járulékos köteget is diagnosztizáltunk. A vizsgálat alatt ortodróm AVRT, illetve a mindkét köteget involváló, antidróm AVRT egyaránt kiválható volt. Mind a két köteg sikeres ablációját végeztük radiofrekvenciás energia használatával, szövődmény nélkül. A beavatkozás óta palpitáció nem fordult elö.

Megbeszélés: Kisebb számban, de strukturális eltérés nélküli szívben is előfordulhatnak többszörös járulékos kötegek, amelyek kezelése lehetséges egy ülésben katéterablációs módszerrel.

Kulcsszavak: járulékos köteg, AVRT, katéterabláció

Atrio-ventricular reentry tachycardia, without involvement of the AV node - dual accesory pathway in young, otherwise healthy patient

Introduction: The prevalence of WPW syndrome in normal population is $0.15-0.25 \%$. Among patients with Ebstein anomaly the presence of multiple accessory pathways (AP) is more frequent (52\%), while among patients with structurally normal heart it occurs rarely (13\%). In symptomatic WPW syndrome the gold standard treatment is catheter ablation .

Case presentation: 41 year-old male patient was admitted to our clinic without history of any known diseases. Three months before admission, the patient was presented with regular, narrow QRS tachycardia, which was terminated with i.v. adenosine. Two weeks before the present admission, wide QRS tachycardia evolved, electrical cardioversion was performed. Transthoracic echocardiography showed preserved left ventricular ejection fraction (LVEF: 60\%), without any valve disease or wall motiont abnormality. On resting ECG delta wave was present with very short PR interval. Electrophysiological study was performed, which revealed rigth and left AP-s with orthodromic AVRT involving the right AP and antidromic AVRT involving both AP-s. Successful radiofrequency catheter ablations of both AP-s were performed without any complications. Since the ablation no arrhytmias occured.

Discussion: Rarely, multiple accessory pathways may be present in patients without any structural heart disease, which can be treated simultaneously with catheter ablation during the same procedure.

Keywords: acessory pathway, AVRT, catheter ablation 


\section{Bevezetés}

WPW-szindrómáról beszélünk azon betegek esetében, akiknél anterográd vezető járulékos köteg (delta-hullám) és tachyaritmiás panaszok is jelen vannak. A WPW-szindróma prevalenciája az átlagpopulációban 0,15-0,25\%, WPW-szindrómával élő első fokú rokonok esetében magasabb, 0,55\% (1). Ebstein-anomáliával élő betegek között gyakori (52\%) a többszörös köteg jelenléte, míg a fejlődési rendellenesség nélküli, strukturálisan ép szívü betegekben jóval ritkább (13\%).

$A$ járulékos köteget a mitralis és tricuspidalis anulus körüli elhelyezkedése alapján nevezzük el, illetve két tulajdonsággal jellemezzük: vezetési irány és refrakteritás. Járulékos köteggel élőknél az esetleges pitvarfibrillációs epizód hirtelen szívhalálhoz vezethet, amennyiben a járulékos köteg anterográd refrakteritása kellően alacsony (2).

$\mathrm{Az}$ Európai Kardiológiai Társaság ajánlása alapján WPW-szindrómával, illetve járulékos köteget mutató EKG-eltéréssel élő pácienseknél elektrofiziológiai vizsgálat, valamint szükség esetén katéterabláció végzése ajánlott, mint elsőként választható terápiás módszer. A katéterabláció magas hatékonyságú és alacsony kockázatú módszer a járulékos köteggel élő betegek kezelésére (3).

\section{Esetbemutatás}

41 éves férfi beteg jelentkezett Klinikánkon ismert belgyógyászati betegség nélkül. Ez év márciusá- ban intravénás adenosinra szűnő, reguláris, keskeny QRS-tachycardia miatt kezelték, majd júliusban széles QRS-tachycardia miatt kardioverzió történt. Nyugalmi szívultrahangon jó bal kamrai ejekciós frakció (LVEF: $60 \%$ ) igazolódott, falmozgászavar, vitium nélkül. EKG-n delta-hullám volt látható, rendkívül rövid PR mellett (1. ábra).

Az ajánlásoknak megfelelően elektrofizológiai vizsgálat mellett döntöttünk, amelyet a Klinikánkon alkalmazott standard 3 elektródás módszerrel végeztünk el. A vizsgálat során tízpólusú katétert helyeztünk el a sinus coronariusban (CS) és egy-egy négypólusú katétert magas jobb pitvari (RVA) és jobb kamracsúcsi pozícióban (RVA). A beavatkozás során reguláris keskeny (2. ábra) és széles (3. ábra) QRS-tacycardia is indukálható volt. Amint a mellékelt ábra mutatja, orthodrom AVRT során a legkorábbi pitvari aktiváció a HRA-katéteren volt látható, amiből retrográd vezető jobb laterális járulékos kötegre következtethettünk.

Antidróm AVRT során is a HRA-katéteren regisztráltuk a legkorábbi pitvari aktivációt, tehát egy olyan AVRT-t regisztráltunk, amely egyik kötegen anterográd vezet a kamrára, a másikon retrográd a pitvarra, kihagyva az AV-csomót.

Különböző pitvari stimulációkkal folyattuk a beavatkozást. HRA-ingerlés alatt jobb laterális kötegvezetésre utaló delta-hullámot láttunk (4. ábra), míg CS-ingerlés során bal laterális kötegvezetés (5. ábra) ábrázolódott. Tehát az elektrofiziológiai vizsgálatunk bidirekcionálisan vezető jobb laterális és anterográd vezető bal la-

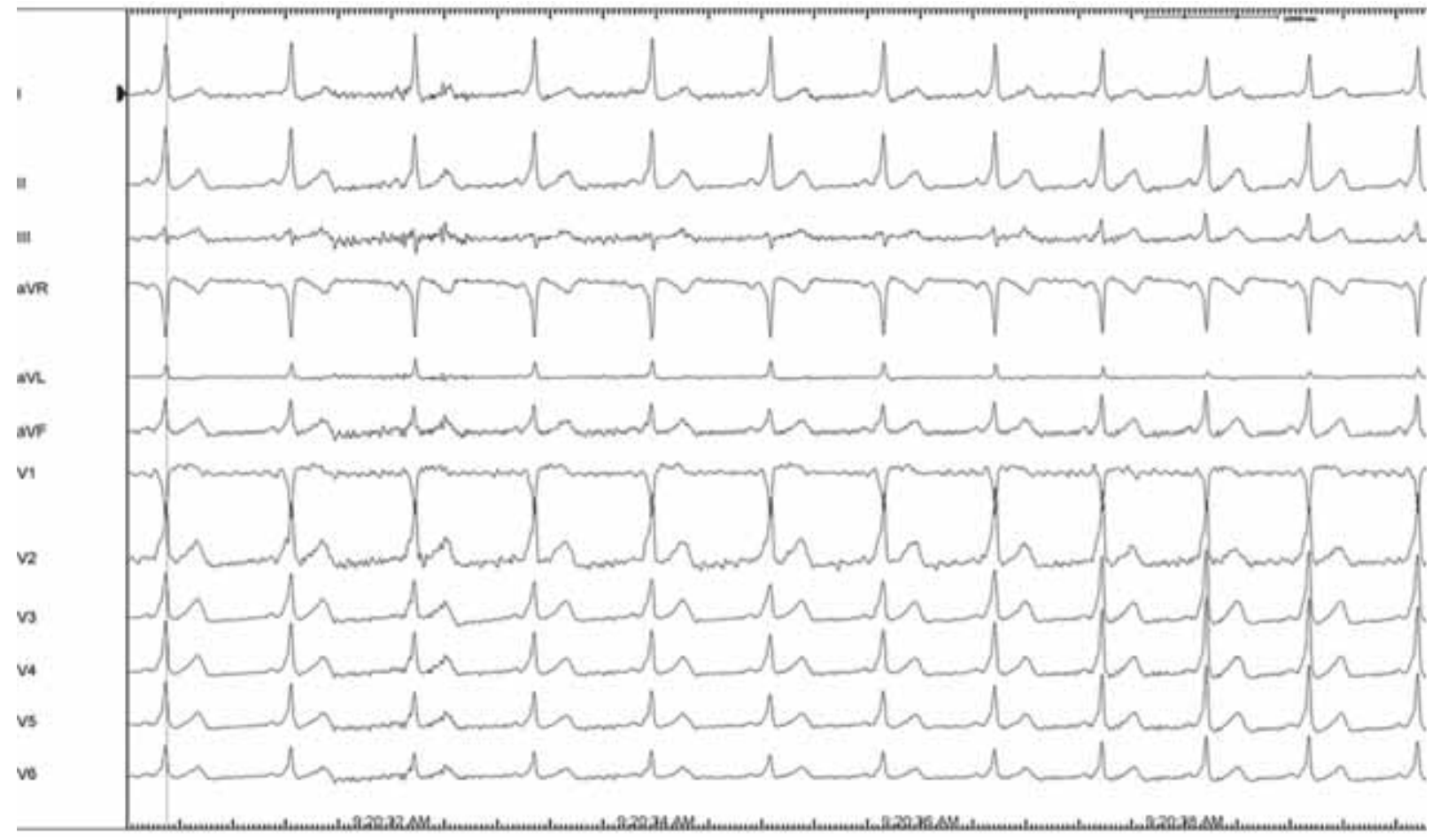



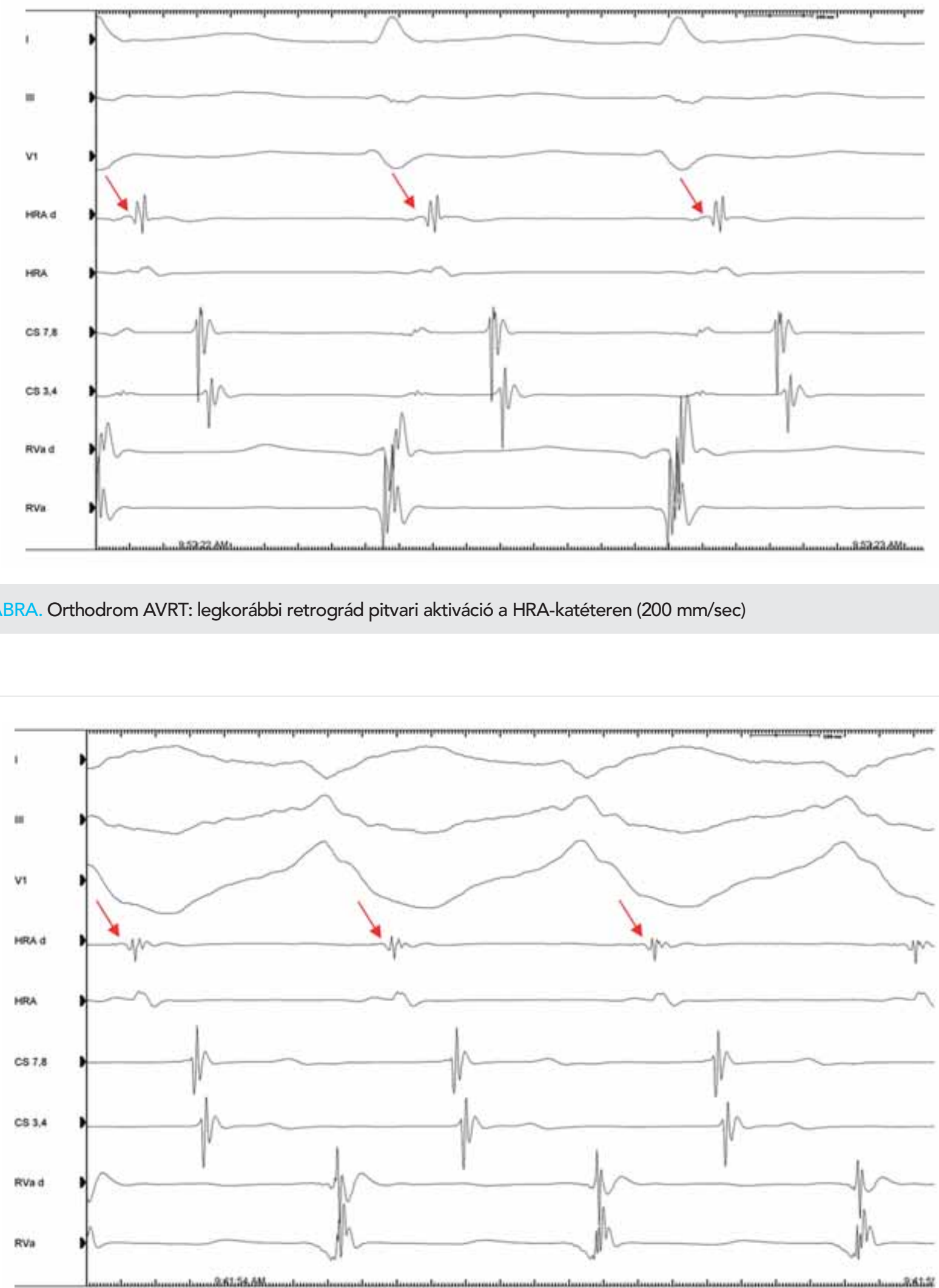

3 ÁBRA. Antidróm AVRT: teljes preexcitációjú széles QRS látható - utalva a bal laterális járulékos kötegen keresztüli anterográd aktivációra, illetve a legkorábbi retrográd aktiváció a HRAd-póluson a jobb pitarban mutatkozik - utalva a jobb oldali járulékos kötegen keresztüli retrográd aktivációra (200 mm/sec). A ritmuszavar nem involválja az AV-csomót! 


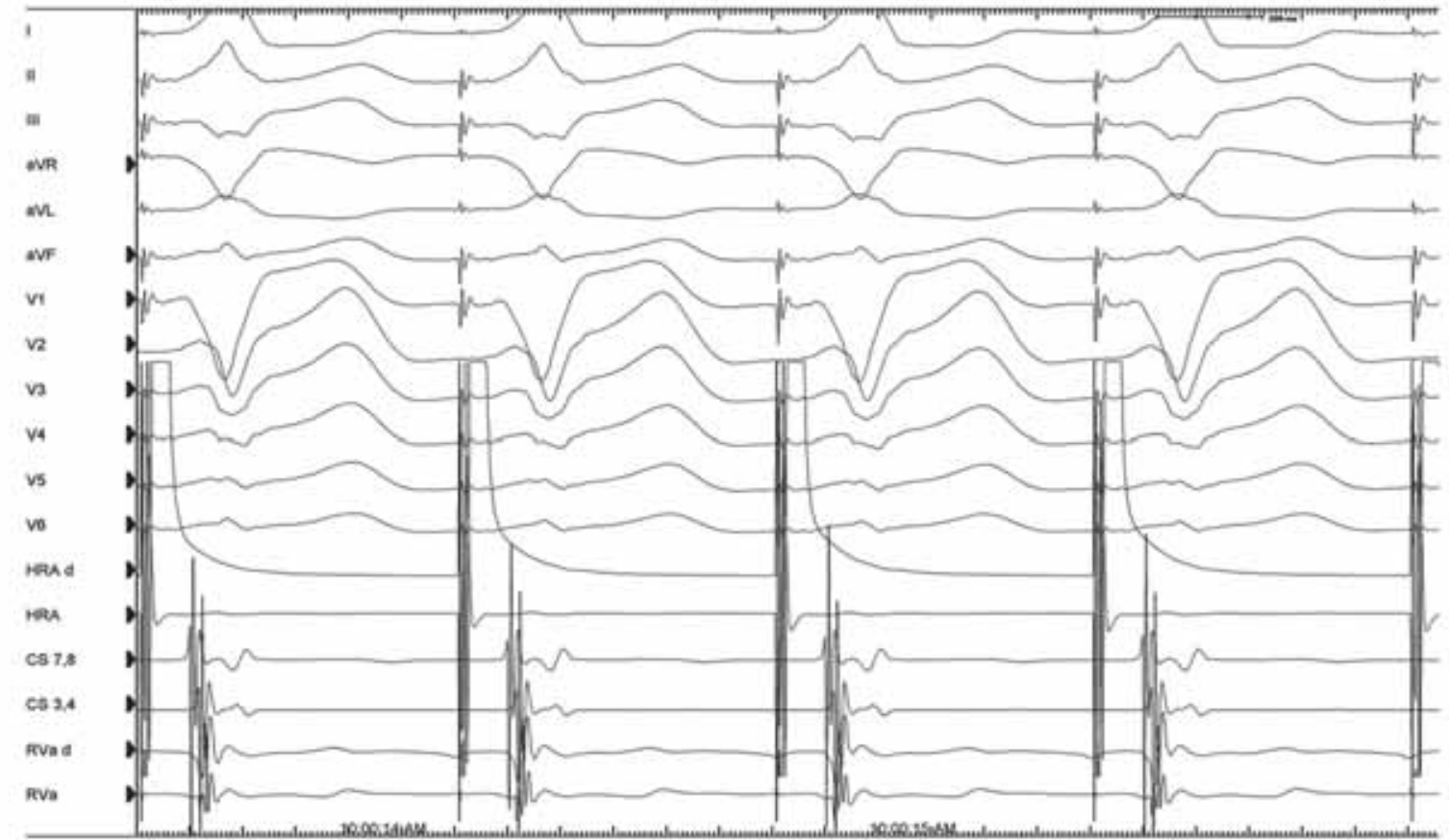

4. ÁBRA. HRA-ingerlés: anterográd vezető jobb laterális köteg (100 mm/sec)

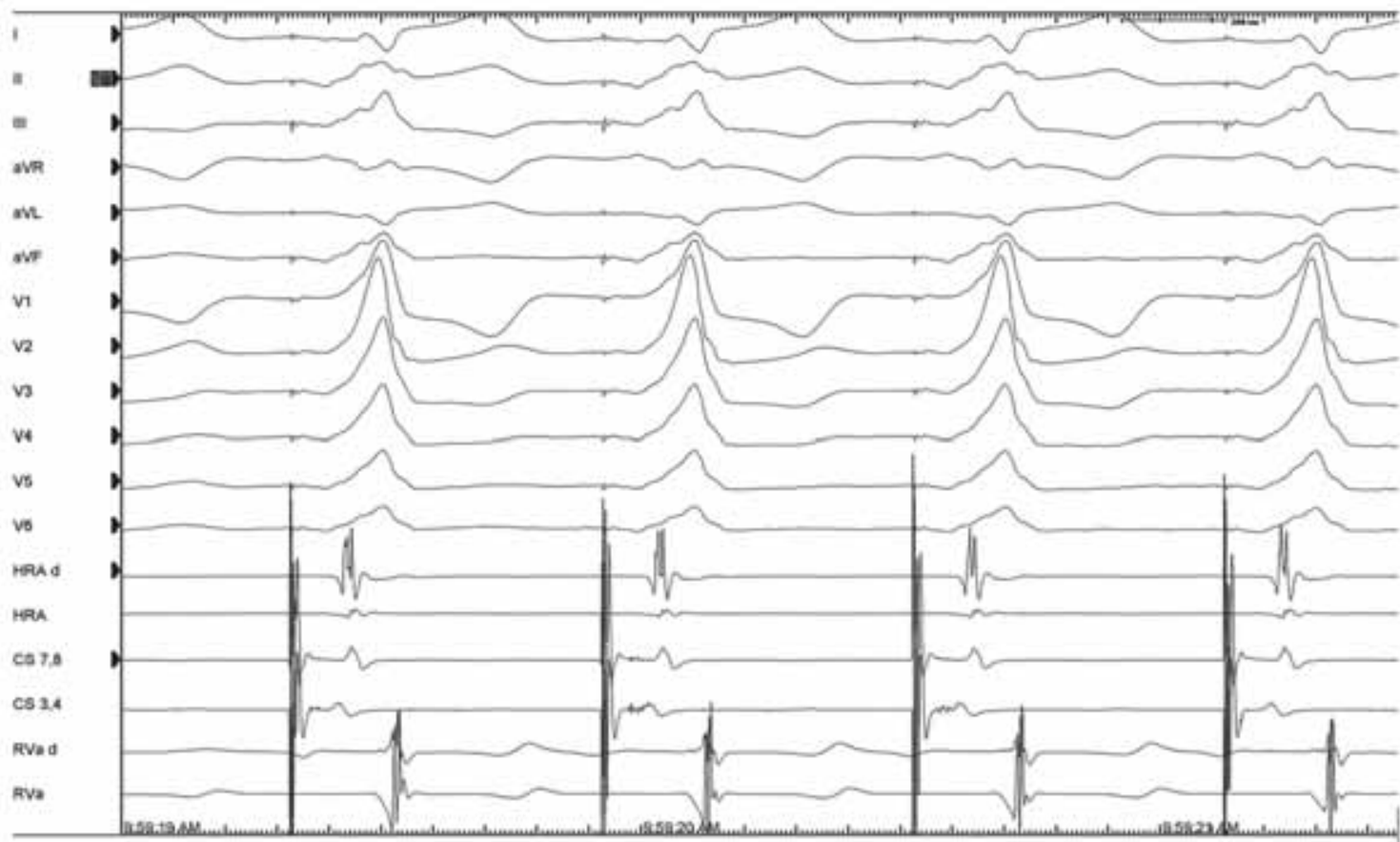

5. ÁBRA. CS-ingerlés: anterográd vezető bal laterális köteg ( $100 \mathrm{~mm} / \mathrm{sec}$ )

terális járulékos köteget igazolt. Az ajánlásoknak megfelelően a beteggel történt egyeztetést követően a kötegek katéterablációja mellett döntöttünk.
A bal oldali járulékos köteg ablációját retrográd behatolásból, femoralis artérián keresztül végeztük el AICath Blue non-irrigációs ablációs katéterrel. 


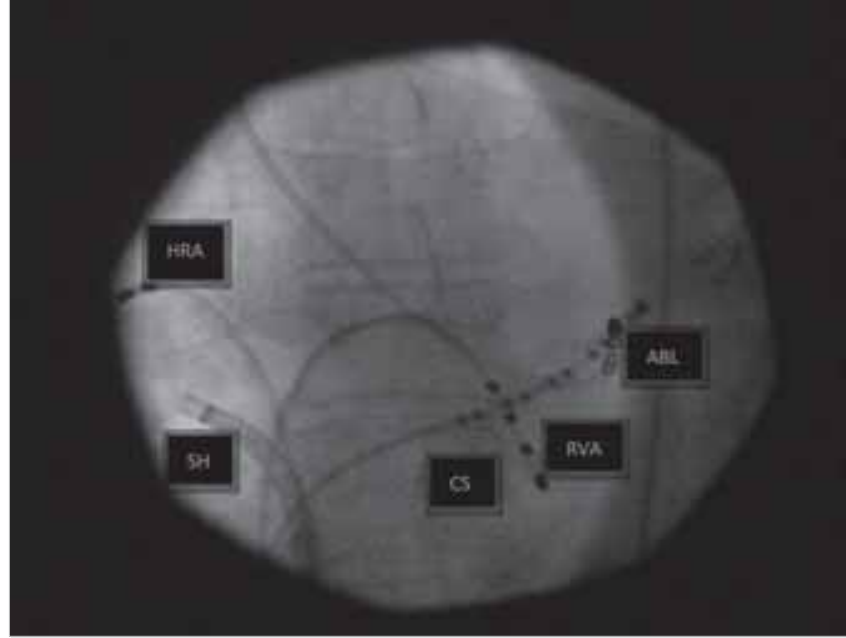

6. ÁBRA. Bal laterális járulékos köteg abláció retrográd behatolásból. CS-tízpólusú sinus coronarius katéter. HRA: négypólusú magas jobb pitvari katéter; RVA: négypólusú jobb kamra csúcsi katéter; $\mathrm{ABL}$ : AlCath Blue ablációs katéter, SH: hajlítható sheath, amit a jobb laterális köteg ablációjára használtunk a jobb kontakt kialakításáért

Abláció alatt a bal laterális járulékos kötegvezetés megszűnt, jobb oldali kötegvezetés maradt vissza (6-7. ábra).

Ezt követően a jobb laterális köteg ablációjával folytattuk a beavatkozást. Hosszú, hajlítható shethen keresz- tül vezettük az ablációs katéterünket a jobb pitvarba, majd sikeresen, szövődménymentesen elvégeztük az ablációt. Eredményünket RVA-ingerléssel ellenőriztük (8. ábra).

A beavatkozás végén készített EKG-n delta-hullám nem látható (9. ábra).

A beavatkozás óta eltelt egy év alatt a páciensnél palpitációs panasz nem jelentkezett, EKG-n delta-hullám továbbra sem látható.

\section{Megbeszélés}

Amennyiben palpitációt panaszoló páciensünknél EKG-n delta-hullám látható, úgy mihamarabbi elektrofiziológiai konzílium szükséges. A katéterabláció a járulékos köteg kezelésére szolgáló megbízható, biztonságos módszer. Kisebb számban, de strukturális eltérés nélküli szívben is elöfordulhatnak többszörös járulékos kötegek, amelyek kezelése biztonságosan elvégezhető egy ülésben katéterablációs módszerrel. Megfigyelték, hogy együlésben végzett többszörös kötegabláció a beavatkozás idejét nyújtja, illetve növeli a sugárterhelést (4). Szakirodalmi adatok alapján többszörös járulékos köteg jelenléte esetén is hasonló hatékonysággal végezhető el a katéterabláció (5). Tehát többszörös járulékos kötegek ablációja együlésben is sikeresen elvégezhető.

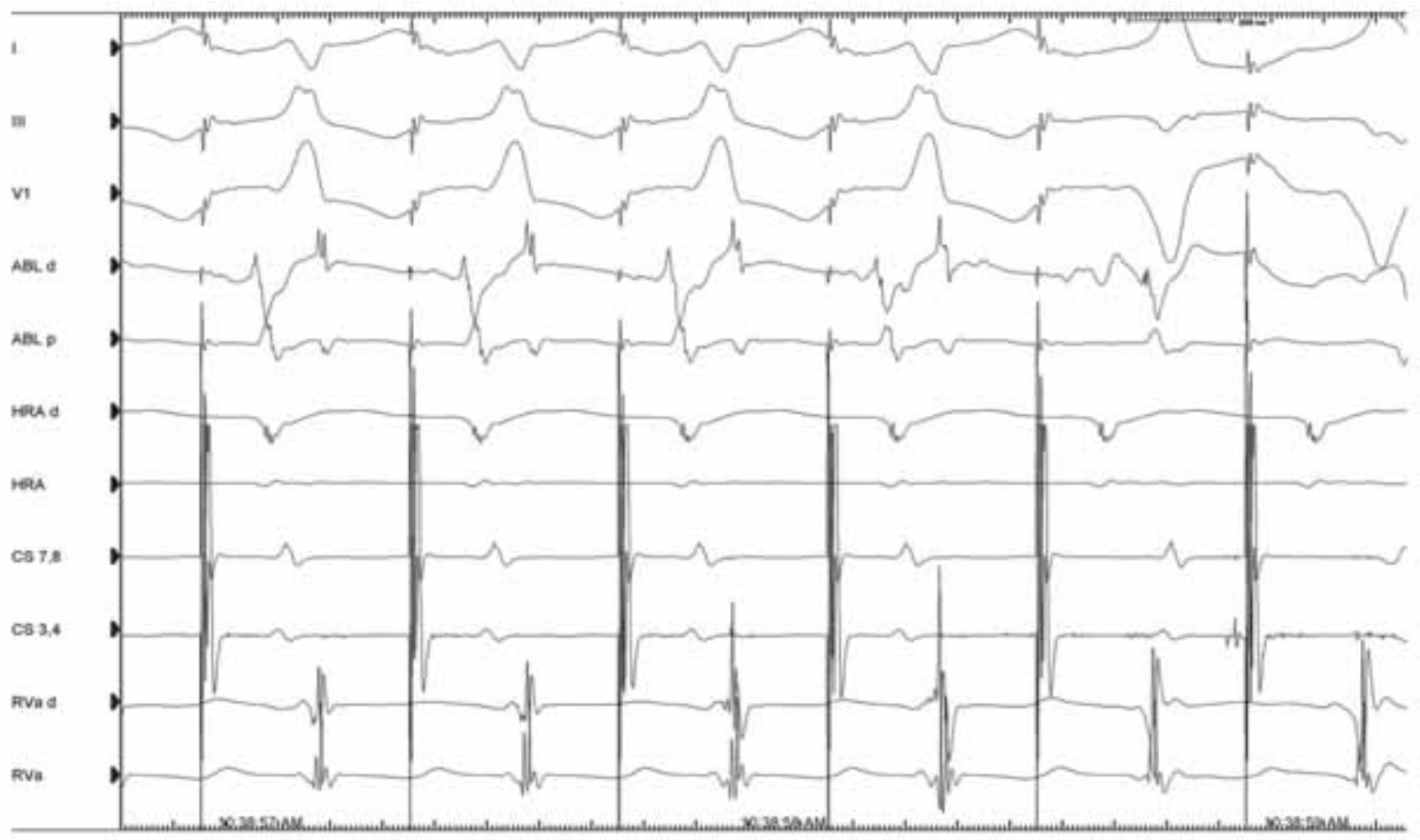

7. ÁBRA. Bal laterális kötegvezetés megszűnése abláció alatt: a QRS-morfológia változik az abláció alatt utalva a bal laterális anterográd vezető köteg vezetésének megszűnésére, a jobb oldali kötegvezetés továbbra is látható (100 mm/sec) 


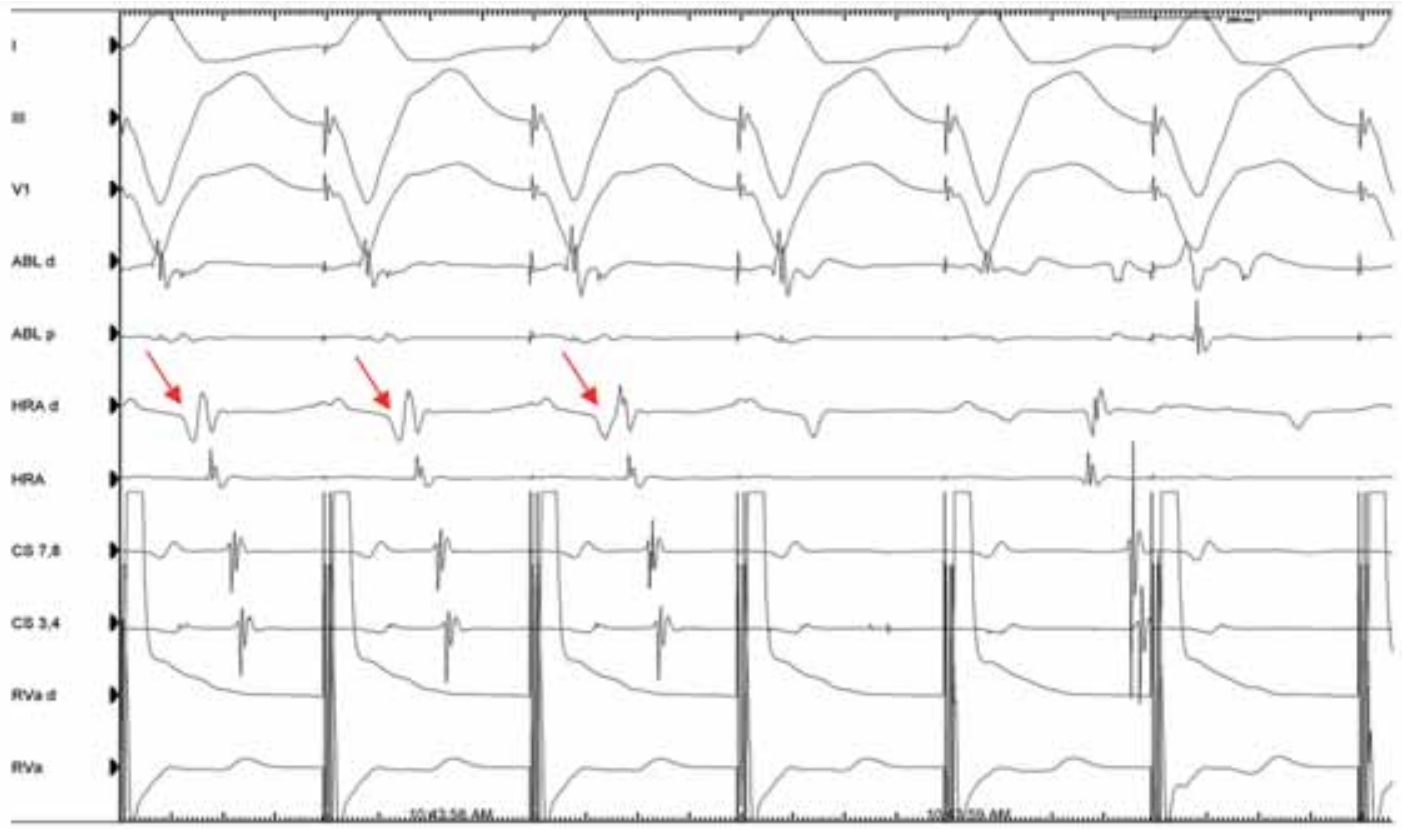

8. ÁBRA. Jobb laterális retrográd (és anterrográd) kötegvezetés megszűnése abláció során RVA-ingerléssel igazolva - a nyíl a retrográd pitvari aktivációt jelzi, amely abláció során szűnik, bizonyítva a kötegvezetés megszűnését (100 mm/sec)

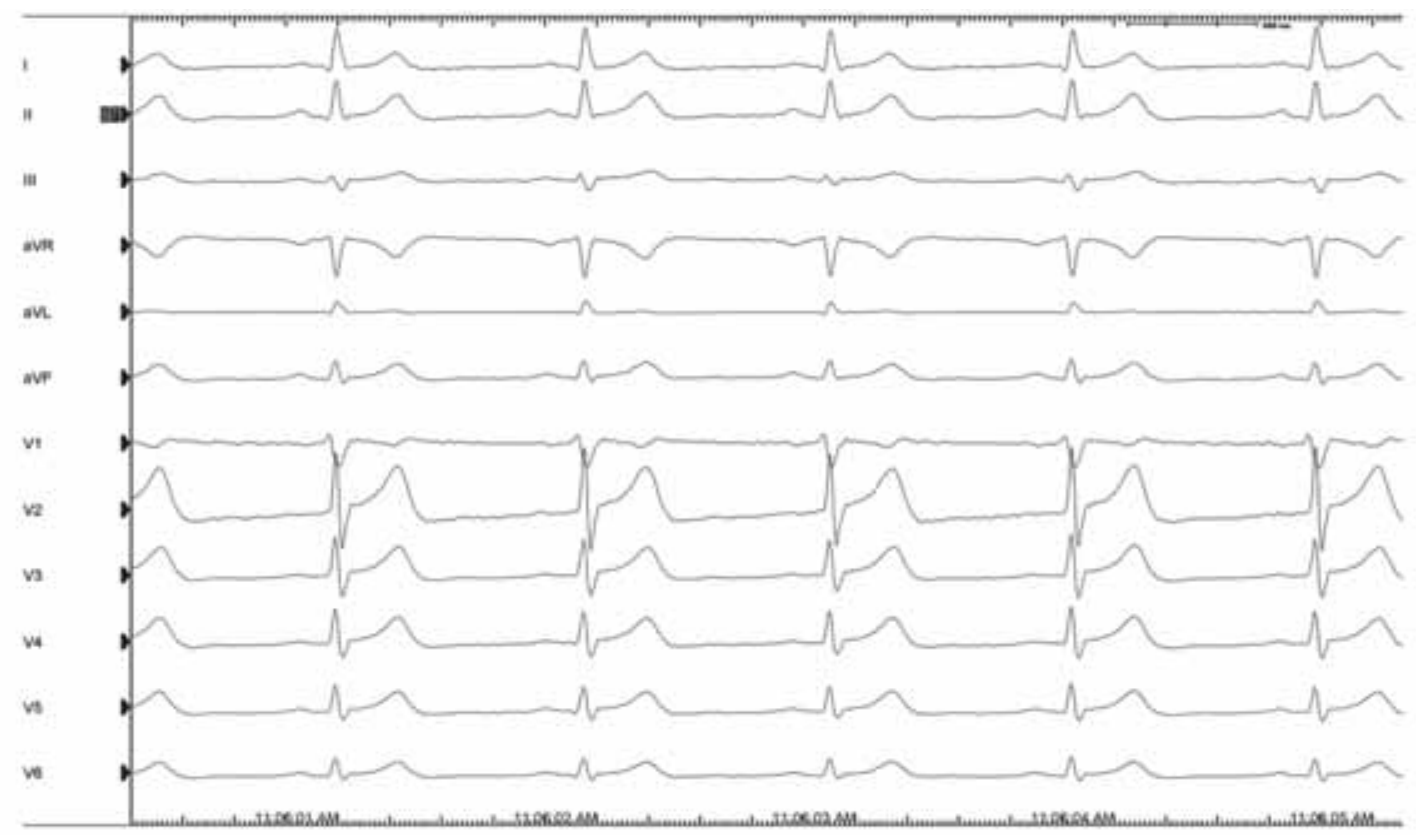

\section{9. ÁBRA. Ablációt követő 12 elvezetéses EKG $(50 \mathrm{~mm} / \mathrm{sec})$}

\section{Irodalom}

1. Vidaillet HJ Jr, Pressley JC, Henke E, Harrell FE Jr, German LD. Familial occurrence of accessory atrioventricular pathways (preexcitation syndrome). N Engl J Med 1987; 317: 65-9. doi: 10.1056/ NEJM198707093170201

2. Dreifus LS, Haiat R, Watanabe Y, Arriaga J, Reitman N. Ventricular fibrillation: a possible mechanism of sudden death in patients and Wolff-Parkinson-White syndrome. Circulation 1971; 43: 520-7. doi: 10.1161/01.cir.43.4.520

3. Carina Blomström-Lundqvist, Melvin M. Scheinman, et al. ACC/AHA/ESC Guidelines for the Management of Patients With Supraventricular Arrhythmias. 2003. doi: 10.1161/01. CIR.0000091380.04100.84

4. Chen SA, Hsia CP, Chiang CE, Chiou CW, Yang CJ, et al Reappraisal of radiofrequency ablation of multiple accessory pathways. Am Heart J 1993 Mar; 125(3): 760-71. doi: 10.1016/00028703(93)90168-9

5. Zoltan Cs, Csaba F. Multiple Reentrant Tachycardias in a Patient with WPW Syndrome. Pacing and Clinical Electrophysiology June 2005; 28(5): 429-31. 